\title{
Blended Learning: The Post Covid-19 Solution for Higher Education in Kenya (A Case of KCA University)
}

\author{
Dennis Simiyu \\ St. Lawrence University, United States of America
}

\begin{abstract}
The outbreak of COVID-19 and post COVID-19 pandemic has basically reshaped our thinking and how different the global carries out its business from today. There is no doubt that even if the COVID-19 virus is completely suppressed and global lockdown comes to an end, the virus effects will linger. Higher education is one of the areas that have been highly hit by the pandemic. This paper scans through blended learning as the post COVID-19 solution to teaching and learning in higher education, particularly, Kenyan Higher Education with KCA University as a case study.
\end{abstract}

Key Words: Blended Learning, COVID-19, Higher Education, Digitalization, Technology, Five Forces

$\mathrm{T}$ he institutions of higher learning in Kenya have embraced remote assessment and engagement of students during the COVID-19 pandemic period. It is therefore significant for Kenyan universities and colleges to plan for post COVID-19 pandemic and any other wind blowing that might arise later. Blended learning is also called "hybrid learning" it represents a learning model that combines non-formal (online courses) and formal (traditional classroom) methodologies. It is the model that integrates technology to boost learning and delivery of other services. While using KCA University as a case study, the article explains the strategies that the Kenya higher education institutions can use in Post COVID-19 basing on Michael Porters Five Forces which give organizations and firms room to practice their competitive position according to co-ordinates of power and threats. The Michael Porter forces provides useful lens for analyzing strategic moves of players in KCA University and other institutions of higher learning. The data was collected qualitatively through textual analysis from books, journals, individual participation, observation, interview and presented descriptively.

\section{INTRODUCTION}

This paper scans through blended learning as the post COVID-19 solution to teaching and learning in higher education, particularly, Kenyan Higher Education with KCA University as a case study.

COVID 19 pandemic has already reshaped how people do business from now on. Institutions of higher learning are now strategizing on how they will carry out their business after the pandemic. It is important to argue that whatever initiatives they have already started such as digitalization of learning should continue, in fact with more intensity and faster. Some of the strategies that the universities have used during this pandemic should be modified in a more radical way (Kofi, 2020).

Kenyan institutions of higher learning should be working towards getting workable sources of growth and profit. The most recommended post COVID- 19 teaching methodology will be the application of blended learning. Blended learning has been referred to by scholar as the new normal (Norberg et.al 2011). Rose and Gage (2006) have referred to it as the "New traditional Model". However, Norberg (2017) argues that blended learning is not a new methodology but dates to medieval period after the introduction of textbook technology into the classroom. Just like post - modern offered the learning and teaching paradigm.

Graham (2013) defines blending learning as the hybrid learning mode which involves non formal (Online digital) and formal (traditional classroom) methodologies. It is therefore a model of learning that integrates use of technology to boost learning and improve business impact. The Blended learning is the model that institutions of higher learning should adopt (Means et.al.2010). Means sentiments, therefore, shows that the adoption of blended learning model by Kenyan higher education institutions in post COVID- 19 Period will be of great benefit and solution to threats that might arise to the institution in future.

\section{METHODOLOGY}

The paper focused on institutions of higher learning in Kenya with KCA university as the case study. The data was collected qualitatively through textual analysis from books, journals, individual participation as a faculty at KCA, observation, interview to senior officials in Information Technology Department and Faculty Head of departments and results presented descriptively.

\section{LITERATURE REVIEW}

Reviewed literature revealed that, blended learning is the best mode of learning that institutions should adopt to evade future threats. Kyalo and Hopkins (2013) conducted a study at the Kenya Medical College to explore the belief and acceptance regarding online learning and recommended blended learning for higher education institutions because of its flexibility in 
learning. This recommendation by Kyalo and Hopkins was emphasized by a study conducted by Gobler (2013) on ICT requirements in Institution, and it was found that blended learning provides the most efficient learning environment. The study by Mtebe and Sife (2013) advocated for blended learning strategy for universities through their ICT policy and Strategic Development Plan. Nalaila (2015) investigated the competences on designing and implementing blended learning among the lecturer and students at Mzumbe university in Tanzania and found out that most teachers and students lucks competency in using blended learning method because there was no adequate training experience. Dziban (2018) in research about newness in blended learning concludes by saying that blended learning is a new normal and must be embraced.

\section{Where Should Kenyan Institutions of Higher Learning Start?}

In the interview with Director of information Technology and head of Distance Learning (DL) at KCA University, I asked them to give a description on how they started offering online classes after the outbreak of COVID-19 in 2020 and whether at some point they used blended learning and if they intend to continue using it. Their response was that the first step was to scout the operational territory which is KCA university by exploring the administrative and technological environment with the aim of ascertaining what is possible and desirable to do. While explaining the importance of scouting as the first step for blended learning, Ko and Rossen (2017) emphasizes that looking at the tools being used by the institution and the institutional policies that can enable or constrain the process influences how institutions sketch out blended learning and how it can take place. They also said blended learning was used at some point but was later dropped. They also said that they are not sure if they plan to use blended learning in future, but they hope to do so.

The institutions of higher learning in Kenya and anywhere else do not exist in vacuum. They have computer support personnel, department heads and administrators who have budget and agendas. However, at this stage, the mode of learning should overrule other expenses because for blended learning to pick up, there must be computer software platforms, hardware, computer labs, instructor training, maintenance, and support. This is the most important part of blended learning program because it involves finance and making serious decisions (Ko and Rossen 2017). While scouting Ko and Rossen highlights the following important questions that individuals and institutions must ask themselves:

Do you have any courses being offered online or on blended learning? If yes, which courses? who teaches them? What software and tools do they use? Are the special staff that helped to put the courses together available, and can they help with blended learning course development and design? How long did they take to put the courses together? Can asynchronous tools be used as well as synchronous? Is their training for faculty and other members of staff? Is there orientation to prepare both the technical staff and students for online learning? (Ko and Rossen, 2017: 24)

The information gained from the above questions is the most valuable you can gather. It lays a ground to forge a strategic plan for developing a blended learning design. It is also important to apply the Five Forces theory at scouting stage because it helps institutions to make choices of significance that involves budgeting.

\section{Five Forces Theory}

The Five Forces framework by Michael Porter can work better in this case. This framework allows institutions of higher learning to familiarize their competitive locus to coordinates of threats and power. This kind of thinking will provide lens which the institutions can use to analyze strategic steps and moves those different players within the industry will take (Porter, 2008). Therefore, as we anticipate future disruption in education sector, adopting Porter's framework shall be a basic strategy going forward.

Porter Framework recommends four major priorities which the institution of higher learning will have to put their strategic radar after the pandemic. They include: First, KCA University and Kenyan Institutions should work on how it will survive and resilience before focusing on economic efficiency. While implementing this strategy, redundancy will have to outplay efficiency with regards to rudimentary resources. This decision increase reliability (Magretta, 2011). The institutions are therefore advised to engage in nurturing long term relations with organizations and companies rather than squeezing every cent. The fissures exposed by the pandemic are self-explanatory.

Secondly, the university should be ready to plan for environmental and ecological threats by quantifying them instead of just describing them. Most departments and faculties have been analyzing different types of threats facing them in in descriptive manner with little or without in-depth forethought on how they will deal with them in case they arise. They do what Magretta (2001) referred to as "Scenario planning". In the recent past, the world had experience different calamities such as the 1918 pandemic which affected a third of the world population, two world wars, terrorism, and increase in global population, climate change and even inequality. They have increased the likelihood of such threats like what we are experiencing now "Covid - 19 pandemics" to re- occur in future. The results from the interview with KCA university audit department officials indicated that before COVID-19, treats were being described rather than quantifying them and they had to re-strategize when COVID19 came in because it got them unprepared. Therefore, they strongly agreed that blended learning should be used by the university even after COVID-19 pandemic is over.

It is therefore the responsibility of the institutions of higher learning to ensure that they allocate more resources for quantifying different types of threats. The main objective should not be accurate but plan for unimaginable events 
(Dumpit and Fernandez, 2017). For example, institutions of higher learning can analyze social media sentiments to quantify political risks. In 2007, Kenyan institutions including KCA university were forced to close because of the postelection violence and that has been the trend every election year. The implementation of blended learning in these institutions will provide a long-term solution to such political challenges in future because learning will continue online after suspension of in-person classes.

The institutions of higher learning should avoid maximizing short term profits but build a very robust organizational invulnerable system that takes hard truths seriously and work on them. Although technology can come in as a solution to some threats as an important part of the package, it cannot overcome a deep root anti- path to hard truths (Rainer and Turban 2009). The management should not tolerate the culture of fear because it brings in insensitivity by different players in repenting threats quickly. Implementing blended learning requires institutions to invest heavily on resources such as software's, hardware, trainings, computer labs, internet, technical support staff and time. This requires courage and organizational skills.

Lastly, it is important that institutions of higher learning integrate government politics. Globalization had a good run in the last decade. However, COVID - 19 pandemics has managed to chop off global supply chains. Therefore, as the world open after COVID-19, the most beneficiaries will be firms and institutions that integrate government politics on their strategies. For example, the institutions can contribute towards government initiatives, creating jobs for youths among others. Therefore, Kenyan institutions of higher learning should embrace government initiatives such as "Kazi kwa Vijana" so that they can also benefit from it. For example, the government can donate computers to your institution if you support their policy on online jobs.

Talking about the four strategies, they do not work in isolation (Magretta 2011). They work in inter-relationships. It is important to underscore that post Covid strategy will be more of dealing with unseen enemy like inequality, climate change, pandemics, and social political woes rather than defeating our competition. It is therefore a wide stakeholder's collaboration and KCA University and other institutions of higher learning should focus on implementing blended learning because it is the best strategy to survive if the unseen enemy/calamity sprouts out.

It is therefore through the Porter's framework and recommendations that this study presents blended Learning as a solution for future (Post COVID 19) threats to institutions of higher learning.

According to that for institutions of higher learning to effectively utilize and enjoy the benefits of blended learning, they must introduce the following specific steps that are discussed below.

\section{Step by Step Process of Implementing Blended Learning}

The implementation of blended learning follows the following steps:

First, the institutions of higher learning should research and make a choice of suitable learning management system (LMS). The choice of LMS should be a product of research by the institution, putting in mind blended learning strategies and learners need. For instance, KCA university is currently (during Covid 19 Pandemic) using Moodle platform as a Learning Management System. However, the institution is advised to do further research on effectiveness of the platform before it is used in post COVID- 19 Period.

Secondly, the institutions through the management and faculty should make a formal communication internally on the objectives of blended learning. It is important for the institutions, department and instructors to inform the learners why, how, and when they will use technology in their learning process. Let learners understand how face to face instructional method will work in combination with use of technology (Garrison and Vaughan 2013).

There should be flexibility in blending learning strategy. It is important to argue that blended learning with strategy but without flexibility might be ineffective. The institutions are advised to organize, and form focus group of employee and learners to test the training materials and Learning Management System before the official launch of blended learning.

Assessment plays an important role in the learning process (Arum et. Al.2016). Institutions, therefore, must include an effective assessment in the system/program. The management through different faculties should establish which courses will have in person assessment and online. For example, in faceto-face assessment the faculty members can plan for pre and post assessment for learners, on the other hand they can offer online assessment at the end of the topic, lecture or course. Blended learning should be able to offer multiple choice, open book, single choice questions among other interactive assessments.

The last step is for the institution to build a blended learning community. There is nothing good like being part of a community that effectively supports an engagement and training which is technologically assisted. The institution is therefore mandated to ensure that the non-teaching staff, faculty members and learners are fully involved in the process of establishing blended learning. By doing so, they will create a community of learners and teachers who empress blended learning system.

The above discussion and implementation process is based on the role of management. However, (McGrow 2017) alludes that, strategies for blended learning implementation can only be effective if presented to learners. He therefore recommends three strategies teachers can use in implementing blended learning. The strategies include: 


\section{Station Rotation}

According to McGrow (2017), station rotation requires an instructor to break learners into smaller learning communities whereby each small group of learners collaborates on some tasks in every station. These groups are required to complete the collected task within the allocated class time. This strategy allows learners to accomplish different tasks within the lesson by use of technology and other ways. It also allows instructors to align a range of learning activities to the learning objectives while closely monitoring the student's progress as they actively engage in the content. Various free programs or lowcost offer instructors an efficient way that enables students to practice using materials with direct feedback upon accomplishment demonstrating development on the standards. Towards the end of online learning station period, in-person learners progress to the subsequent station, with learners at home effectively joining virtual, small-group station.

To explain the rotation model, Gaudo (2019) uses the diagrammatic presentation shown below:

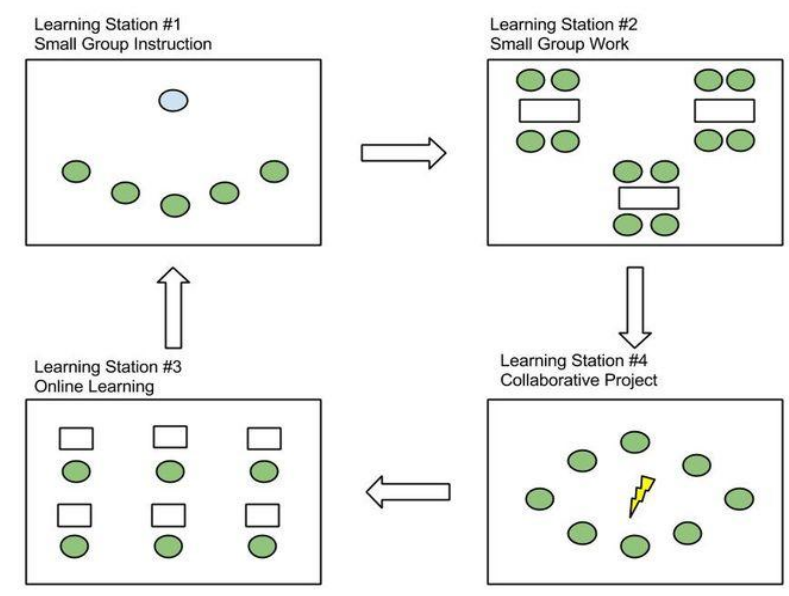

Credit: BLOGLOVIN'

\section{Flipped Classroom}

This strategy involves use of distance and online learning. It involves knowledge transfer by use of interactive and recorded lecture using technology. Consequently, the learners will explore and engage with the content during face to face, mortar on brick learning environment.

\section{Whole Group Protection}

This strategy is almost like station rotation because it also allows instructors to move from task to task. However, the strategy does not allow learners to form small groups. The strategy is appropriate for instructors who have small class sizes that cannot allow small group discussions. However, the approach gives room for instructors to use in person instruction purposefully and creatively. It has to be designed in a way that balances the offline and online experiences, encourages both collaborative and individual work, allows students to evaluate their learning experiences and enables the teacher to plan when to work directly with students for guidance, additional support of feedback.

\section{DISCUSSION OF FINDINGS AND RECOMMENDATION}

The world has experienced different threats with COVID-19 being one of the worst. Higher education has been affected negatively by COVID whereby institutions of higher learning were closed. The institutions have been working hard to ensure that learning resumes without further challenges. This paper finds that institutions of higher learning such as KCA university have established online learning to ensure that learning is not disrupted. However, they are not sure whether to continue with online learning as students return to campus. This study finds that institutions of higher learning should blended learning to avoid interfering with learning if the world of even Kenya experiences other threats equivalent to COVID.

There are several reasons why higher education institutions should implement the blended learning system. Some of the benefits include: - The model is cost - efficiency in most cases the university will forget about travelling costs and it improves constant training (Lowe, 2013). The model gives room for combination of classroom trainings and preregistered courses. The learners will be up-to date with information and learning materials (Becker, et. al. 2017). The model also allows learners and teachers to access learning content from any device, anywhere and anytime. Therefore, it ensures that the learners are constantly connected to instructor's content and can download causes so that they can access them later even without necessarily being connected to internet (Dziuban and Moskal 2011).

Through blended learning instructors gets immediate feedback from the learners. The instructor can analyze different activities that learners undertake. Therefore, it gives room for evaluation that acts as an indicator for instructors to identify whether learners are excelling or struggling (EDUCAUSE, 2007). Hence, optimizing the content accordingly. The triangulation of instructional and multi- media design provides a perfect recipe and rich experience for learning (Florid 2014). The most important thing in this context is that learners have an opportunity to go back and recheck the courses any time they want. Such an activity can deliver great output over time.

This study recommends that the KCA university and other institutions of higher learning should adopt the Five Forces theory and utilize it to establish blended learning. This requires resources and sacrifices for services rather than profit.

\section{CONCLUSION}

It goes without mentioning that the discussion in this paper gives an outline on the way forward for institutions of higher learning. It is therefore the responsibility of this institutions to start thinking beyond Covid-19 and decide on how learning should take place in future without interference even in the 
face of storms. This paper has argued that blended learning will effectively serve as the best learning model for institutions for higher learning in post-Covid-19 if adopted and implemented accordingly.

The aim of introducing blended learning program is to ensure Kenyan higher education is stable and improve the academic performance and achievement of students during eventuality learning circumstances. It also develops adaptive and resilient teachers equipped for flexible, digital age instruction by having a better institution and even community readiness for both long- and short-term learning interruptions.

\section{REFERENCES}

[1] Becker, A., Cummins, M., Davis, A., Freeman, A., Hall Giesinger, C., \& Ananthanarayanan, V. (2017). NMC horizon report: 2017 higher Education Edition. Austin: The New Media Consortium.

[2] Dumpit, Z. \& Fernandez, J. (2017). Analysis of Use of Social Media in Higher Education Instituitions (HEIs) Using the Technology Acceptance Model. International Journal of Educational Education Technology in Higher Education. 4(5)

[3] Dzuiban, (C. 2018) Blended Learning: The New Normal and Emerging Technologies. International Journal of Educational Technology in Higher Education volume 15,

[4] Dziuban, C., \& Moskal, P. (2011). A Course is a Course: Factor Invariance in student Evaluation of Online, Blended and Face-toFace Learning Environments. The Internet and Higher Education, 14(4), 236-241. Dziuban, C., Moskal, P., Hermsdorfer, A., DeCantis, G., Norberg, A., \& Bradford, G., (2015) A Deconstruction of Blended Learning. Presented at the $11^{\text {th }}$ annual Sloan-C blended learning conference and workshop

[5] Dziuban, C., Picciano, A. G., Graham, C. R., \& Moskal, P. D. (2016). Conducting Research in Online and Blended Learning Environments: New pedagogical frontiers. New York: Routledge, Taylor \& Francis Group.

[6] Dziuban, C. D., Hartman, J. L., \& Moskal, P. D. (2004). Blended Learning. EDUCAUSE Research Bulletin, 7, 1-12.

[7] EDUCAUSE. (2017) 2017 Key Issues in Teaching \& Learning. Retrieved from https://www.EDUCAUSE.edu/eli/initiatives/keyissues-in-teaching-and-learning

[8] Floridi, L. (2014). The 4th Revolution: How the Infosphere is Reshaping Human Reality. Oxford: Oxford University Press.

[9] Gaudo, M. (2019) How to Put the Six Blended Learning Models in to Action. https://www.prodigygame.com/blog/six-blendedlearning-models-examples-download/

[10] Graham, C. R. (2013). Emerging practice and research in blended learning. In M. G. Moore (Ed.), Handbook of distance education, (3rd ed., pp. 333-350). New York: Routledge.

[11] Harari, Y. (2020) The World after Corona Virus. Financial Times, March 20th

[12] Kitchenham, A. (2011). Blended Learning Across Disciplines: Models for Implementation. Hershey: information Science Reference.
[13] Kofi, S. (2020). What will Higher Education in Afrika Look Like after Covid-19? https://www.weforum.org/agenda/2020/06/highereducation-africa-covid19-coronavirus-digital- online/

[14] Kyalo, W. and Hopkins, S. (2013) Exploring the Acceptability of Online learning for Continuous Professional Development at Kenya Medical Taraining Colleges. Electronic Journal of eLearning 11(2):82-90

[15] Lowe, D. (2013). Roadmap of a Blended Learning Model for Online Faculty Development. Invited Feature Article in Distance Education Report, 17(6), 1-7.

[16] Magretta, J. (2011) Understanding Michael Porter: The Essential Guide to Competition and Strategy. Havard Business Review

[17] Means, B., Toyama, Y., Murphy, R., \& Baki, M. (2013).The Effectiveness of Online and Blended Learning: A metaanalysis of the empirical literature. Teachers College Record, 115(3), 1-47.

[18] Means, B., Toyama, Y., Murphy, R., Kaia, M., \& Jones, K. (2010). Evaluation of Evidence- Based Practices in Online Learning. Washington: US Department of Education.

[19] Moskal, P., Dziuban, C., \& Hartman, J. (2013). Blended learning: A dangerous idea? The Internet and Higher Education, 18, 15-23.

[20] Mtebe, J \& Raphael, C. (2013). 'Students' experiences and challenges of blended learning at the University of Dar es Salaam. International Journal of Education and Development using Information and Communication Technology" (IJEDICT). Vol. 9, Issue 3, pp. 124-136. DSM, UDSM

[21] Nolaila, S. (2015) "Use of Information and Communication Technology for Teaching and Learning at Mzumbe University in Tanzania." (Masters dissertation, Kenyatta (University)

[22] Norberg, A. (2017)." From Blended Learning to Learning Online: ICTs, Time and Access in Higher Education" (Doctoral dissertation, Umeå University).

[23] Norberg, A., Dziuban, C. D., \& Moskal, P. D. (2011). A timebased blended learning model. On the Horizon, 19(3), 207-216. https://doi.org/10.1108/10748121111163913.

[24] Picciano, A. G. (2009). Blending with Purpose: The Multimodal Model. Journal of Asynchronous Learning Networks, 13(1), 7-18.

[25] Picciano, A. G., Dziuban, C., \& Graham, C. R. (2014). Blended Learning: Research Perspectives, (vol. 2). New York: Routledge.

[26] Picciano, A. G., \& Dziuban, C. D. (2007). Blended learning: Research perspectives. Needham: The Sloan Consortium.

[27] Porter, M. (2008) The Five Competitive Forces That Shape Strategy, Harvard Business Review.

[28] Rainer R., and Turban E. (2009), Introduction to Information Systems (2nd edition), Wiley, pp 36-41.

[29] Ross, B., \& Gage, K. (2006). Global Perspectives on Blended Learning: Insight from WebCT and Our Customers in Higher Education. In C. J. Bonk, \& C. R. Graham (Eds.), Handbook of Blended Learning: Global Perspectives, Local Designs, (pp. 155168). San Francisco: Pfeiffer.

[30] Rovai, A. P., \& Jordan, H. M. (2004). Blended learning and sense of community: A comparative analysis with traditional and fully online graduate courses. International Review of Research in Open and Distance Learning, 5(2), 1-13.

[31] Sharpe, R., Benfield, G., Roberts, G., \& Francis, R. (2006). The undergraduate Experience of Blended Learning: A Review of UK Literature and Research. The Higher Education Academy, (October 2006). 